\title{
ROLE OF ALLELOCHEMICALS AND TRICHOME DENSITY IN THE RESISTANCE OF TOMATO TO WHITEFLY
}

\author{
Papel de aleloquímicos e densidade de tricomas na resistência de tomateiro à mosca-branca
}

\author{
Irã Pinheiro Neiva', Valter Carvalho de Andrade Júnior², Wilson Roberto Maluf ${ }^{3}$, \\ Celso Mattes Oliveira ${ }^{4}$, Gabriel Mascarenhas Maciel $^{4}$
}

\begin{abstract}
In Brazil, the tomato is cultivated in almost all geographic regions even though its yield is significantly reduced by pests and diseases. Among these pests and diseases, whitefly is a major problem that causes direct and indirect damage due to its role in transmission of geminiviruses. The aim of the present study was to compare the degree of resistance to the silverleaf whitefly of tomato plant lines rich in acyl sugars (AS), zingiberene (ZGB), and 2-tridecanone (2-TD) and to establish whether selection for strains with higher densities of glandular trichomes promotes sufficient resistance to this insect pest. The investigated lines were developed by performing back-crossings in tomato (Solanum lycopersicum) from the interspecific crossing of $S$. lycopersicum x $S$. habrochaites var. glabratum 'PI 134417'. Lines rich in AS, ZGB, and 2-TD were tested for their levels of resistance to B. tabaci biotype B. Two tomato plant lines (TOM-584 and TOM-679) with normal AS levels and one wild specimen (PI 134417) with high 2-TD content were used as controls. TOM-687, ZGB-703, and TOM-622 were less preferred by B. tabaci for oviposition, and nymphs exhibited a poorer survival rate on those plant lines than on the susceptible controls, TOM-584 and TOM-679. Allelochemicalrich lines exhibited pest resistance, whereas the controls did not, and the allelochemical-rich lines did not differ significantly from each other in the level of resistance. The results show that the development of tomato plant lines rich in 2-TD, ZGB and AS is an effective option for indirect selection for resistance to B. tabaci biotype B. All lines selected based on high trichome density except for BPX365F-751-05-01-03 exhibited fewer nymphs than the susceptible controls, indicating that selection for more glandular trichomes was generally effective in promoting increased resistance to the silverleaf white flay.
\end{abstract}

Index terms: Solanum lycopersicum, 2-tridecanone, zingiberene, acyl sugars, indirect selection.

\section{RESUMO}

No Brasil, o tomate é cultivado em praticamente todas as regiões, embora seu rendimento seja reduzido por pragas e doenças. A mosca-branca, comumente presente, causa danos diretos e indiretos, devido à transmissão de geminiviros. O objetivo do presente trabalho foi comparar o grau de resistência à mosca branca de linhagens de tomateiro ricas em acilaçúcares (AA), zingibereno (ZGB) e 2-tridecanona (2-TD) e verificar se a seleção de linhagens com base em tricomas glandulares é efetiva no sentido de promover níveis satisfatórios de resistência. Essas linhagens foram obtidas através de retrocruzamentos em tomateiro Solanum lycopersicum, a partir do cruzamento interespecífico $S$. lycopersicum x $S$. habrochaites var. glabratum 'PI 1344171'. Linhagens ricas em AA, ZGB e 2-TD foram testadas para níveis de resistência. Duas linhagens de tomateiro (TOM-584 e TOM-679), com nível normal de AA, e o acesso selvagem (PI 134417), alto teor de 2-TD, foram utilizados como testemunhas. TOM-687, ZGB-703 e TOM-622 mostraram diminuições na ovoposição e na contagem de ninfas, quando comparados com os controles TOM-584 e TOM-679. As linhagens ricas nos aleloquímicos mostraram níveis de resistência à praga, relativamente aos controles, e não deferiram significativamente entre si. Os resultados mostram que linhagens ricas em AA, ZGB e 2-TD são eficazes alternativas de seleção indireta para criação de resistência a Bemisia argentifolii. As linhagens selecionadas para maior densidade de tricomas, exceto BPX-365F-751-05-01-03, apresentaram números médios de ninfas inferiores ao das testemunhas suscetíveis, indicando que a seleção para maior número de tricomas glandulares foi efetiva no sentido de promover aumento dos níveis de resistência à mosca-branca.

Termos para Indexação: Solanum lycopersicum, 2-tridecanona, zingibereno, acilaçúcar, seleção indireta.

(Received in october 12, 2012 and approved in december 28, 2013)

\section{INTRODUCTION}

In Brazil, the tomato (Solanum lycopersicum L., syn. Lycopersicon esculentum Mill.) crop is cultivated in virtually every geographic area and is one of the most important crops. Yields are significantly reduced by pests and diseases (FERNANDES et al., 2009).
The silverleaf whitefly, Bemisia tabaci (GENNADIUS, 1889) biotype B (Hemiptera: Aleyrodidae) (= Bemisia argentifolii), is commonly present in plantations, where it causes direct (yield reduction) and indirect damage due to the transmission of geminiviruses. This pest is usually managed by applying insecticides,

\footnotetext{
${ }^{1}$ Universidade Federal de Lavras/UFLA - Cx. P. 3037 - 37200-000 - Lavras - MG - Brasil - iraagronomia@yahoo.com.br

${ }^{2}$ Universidade Federal dos Vales do Jequitinhonha e Mucuri/UFVJM - Diamantina - MG - Brasil

3Universidade Federal de Lavras/UFLA - Departamento de Agricultura/DAG - Lavras - MG - Brasil

${ }^{4}$ Universidade Federal de Lavras/UFLA - Lavras - MG - Brasil
} 
which may cause damage to humans and the environment and may lead to the development of insecticide resistance (BACCI et al., 2007; SILVA et al., 2009).

The use of insect-resistant cultivars is an alternative option for effective pest control (VENDRAMIM et al., 2001; TORRES et al., 2007; VENDRAMIM; SOUZA; ONGARELLI, 2009). Some wild tomato specimens have exhibited satisfactory levels of resistance to insect pests due to the presence of allelochemicals, such as the sesquiterpenes [mainly zingiberene (ZGB)], acyl sugars (AS), and 2-tridecanone (2-TD), in specimens 'PI-127826' of S. habrochaites S. Knapp. \& D. M. Spooner (=Lycopersicon hirsutum), 'LA-716' of S. pennellii Correl (=L. pennellii), and 'PI 134417' of S. habrochaites, respectively (CARTER; SACALIS; GIANFAGNA, 1988; FREITAS et al., 2002; TOSCANO; BOIÇA JÚNIOR; MARUYAMA, 2002).

Brazilian tomato plant breeding programs aimed at developing pest-resistant cultivars have adopted the strategy of incorporating resistance alleles from wild specimens containing resistance-related allelochemicals into commercial cultivars (MALUF et al., 2007). Maluf et al. (2010) assessed the AS-mediated resistance of the tomato plant to arthropod pests and found that hybrids with intermediate AS contents exhibited satisfactory resistance to Bemisia tabaci biotype B and Tuta absoluta (Lepidoptera: Gelechiidae), similar to homozygous lines with high AS contents.

Silva et al. (2009) compared the degrees of resistance to $B$. tabaci biotype $\mathrm{B}$ and Tetranychus urticae (Thysanoptera: Tetranychidae) exhibited by tomato plant hybrids resulting from the crossing of lines with high ZGB and AS contents with those of the parental lines and commercial controls. These authors found that both allelochemicals were effective in conferring pest resistance in both homozygotes and heterozygotes.

Maluf et al. (2007) assessed the correlation between glandular trichome density and resistance to the mite $T$. urticae and found that a high density of glandular trichomes negatively affects the average distance traversed by mites. Therefore, plants with high numbers of trichomes may be selected to develop genotypes resistant to this pest. Aragão, Dantas and Benites (2000) reported that the allelochemical 2-TD has potential for the introgression of resistance to arthropod pests, which can be utilized by selecting genotypes coding for a high density of glandular trichomes.

Although correlations between the concentrations of foliar allelochemicals (2-TD, ZGB or AS) and the degree of pest resistance have been established (ARAGÃO; DANTAS; BENITES, 2000; MALUF et al., 2007; SILVA et al., 2009; GONÇALVES NETO et al., 2010; MALUF et al., 2010), few critical studies have compared the degree of pest resistance among lines rich in different allelochemicals.

Therefore, improved tomato plant lines rich in AS, ZGB, and 2-TD were studied regarding their degree of resistance to the silverleaf whitefly (B. tabaci biotype B) and aimed to establish whether glandular trichome density promotes satisfactory degrees of resistance to that pest.

\section{MATERIALS AND METHODS}

The experiments were conducted in a greenhouse at the Experimental Vegetable Station at HortiAgro Sementes Ltd., Palmital Farm, Ijaci County, MG, and at the Olericulture Unit of the Universidade Federal de Lavras UFLA, Lavras County, MG.

One plant was grown per vase (plot), and six replicates were used for each of 15 treatments, for a total of 90 plants. The seeds of all investigated genotypes were sown in 128-cell polystyrene trays containing the commercial substrate Plantmax ${ }^{\circledR}$. Subsequently, the seedlings were transplanted into $500-\mathrm{mL}$ vases with substrate (ravine soil + manure in 1:1 ratio). The tomato plant lines S. lycopersicum TOM-584 and TOM-679 (exhibiting low AS, ZGB, and 2-TD contents but variable glandular trichome density) and the $S$. habrochaites var. glabratum specimen PI 134417 (with a high 2-TD content) were used as controls. The following tomato plant lines were also tested: TOM-622 (high 2-TD and low AS and ZGB contents), TOM-687 (high AS and low ZGB and 2TD contents), ZGB-703 (high ZGB and low AS and 2-TD contents), and nine genotypes obtained by the selffertilization of plants selected by Maluf et al. (2007) for the highest glandular trichome densities from two advanced tomato plant populations named BPX-365E and BPX-367C. From the nine genotypes that were selected for trichome density, seven (BPX-365F-751-05-01-03, BPX-365F-751-05-02-02, BPX-365F-751-10-01-01, BPX365F-751-10-01-02, BPX-365F-899-07-04-02, BPX-365F899-14-02-03, and BPX-365F-899-14-02-04) corresponded to F7 lines obtained from the crossing of TOM-679 and TOM-600 (from this line, line TOM-622 was selected because it has larger fruits). The remaining two genotypes (BPX-367D-074-02 and BPX-367D-238-02) corresponded to F5 lines obtained from the crossing of TOM-584 and TOM-600. TOM-600 is a 2-TD-rich line selected from the interspecific crossing of a tomato plant and $S$. habrochaites var. glabratum PI 134417, and lines BPX365F and BPX-367D were selected because they exhibited 
the highest glandular trichome (where 2-TD accumulates) density; presumably, the latter two lines also exhibit high 2-TD contents. TOM-687 is an AS-rich line with commercial characteristics that exhibits well-documented resistance to the mite Tetranychus spp., tomato leaf miner Tuta absoluta, and silverleaf whitefly B. tabaci biotype B (MALUF et al., 2010); for this reason, this line was used as the standard resistant line.

For the purpose of infestation by B. tabaci biotype B, as previously identified and used by Silva et al. (2009) and Maluf et al. (2010), silverleaf whiteflies were grown in a protected greenhouse with a $12-\mathrm{m}^{2}$ domed protective structure covered by transparent plastic. Adult insects were randomly collected at several tomato cv. Santa Clara plantations in the Lavras-MG area and transferred to the protected greenhouse. The tomato cultivar Santa Clara was used as a substrate for oviposition and, later, as food for the nymphs. Twenty days after transplantation, when several cv. Santa Clara plants exhibited signs of damage caused by infestation (wilting, leaf drop, small fruits), the various investigated genotypes were transported to the protected greenhouse that had been previously infested by a population of B. tabaci biotype B. Six days after infestation, oviposition was assessed by counting eggs; four leaflets from the upper third of the fourth leaf were sampled using a binocular stereoscopic microscope under $20 \mathrm{X}$ to $80 \mathrm{X}$ magnification. Twenty-three days after infestation, the same sampled leaflets were assessed for nymph development to identify the last instar or pupal stage, also using a binocular stereoscopic microscope.

Once satisfied the assumptions of ANOVA, a fully randomized design was used Analysis of variance was applied to the results of the test of resistance to silverleaf whitefly, and the averages of the genotypes were compared using Tukey's test $(\mathrm{p} \leq 0.05)$ as implemented in the SAS software (STATISTICAL ANALYSIS SYSTEM INSTITUTE-SAS, 1989). Selected contrasts between groups of genotypes with different allelochemical contents were calculated to characterize possible differences in the degree of pest resistance as a function of allelochemical content. Finally, the pearson' correlation between the number of eggs of B. tabaci biotype B and the glandular trichome density of the tomato plant leaflets was assessed (this density was measured in the previous generation by MALUF et al., 2007). The amount of trichomes is similar to that found by Maluf et al. (2007) because we used the same materials, and this analysis merely required counting the trichomes present in the sample, although sampling error may have occurred.

\section{RESULTSAND DISCUSSION}

Oviposition by adults and number nymphs of $B$. tabaci biotype $\mathrm{B}$ were affected by the presence of the allelochemicals 2-TD, ZGB, and AS in the assessed tomato plant genotypes (oviposition: $\mathrm{F}=83,12$, $\mathrm{Pr}>\mathrm{F} 0,0001$; nymphs: $\mathrm{F}=105,77, \mathrm{Pr}>\mathrm{F} 0,0001$ ) (Table 1). Lines TOM-622, TOM-687, and ZGB-703 were less preferred by insect pest for oviposition and interfered with the survival of nymphs more than the susceptible controls TOM-584 and TOM-679.

None of the assessed genotypes was as resistant to the silverleaf whitefly, based on the average number of eggs and nymphs present, as the wild specimen PI 134417 (Table 1). This indicates that this genotype, whose leaflets are rich in methyl-ketones (2-TD in particular), allelochemicals might not be the only factor contributing to resistance to this pest. Similar results were found by Maluf et al. (2007) and Oriani, Vendramim and Vasconcelos (2011). The genotypes corresponding to the F7 and F5 generations, except for genotype BPX-365F-899-07-04-02, were less preferred by the silverleaf whitefly than the control TOM-584, particularly based on the average number of eggs on the leaflets (Table 1). Nombela and Muñiz (2010) found the satisfactory resistance of tomato plants to $B$. tabaci biotype B to be mediated by the isolation and cloning of the gene Mi-1. This preference for non genotypes under study, may be associated with gene activity Mi-1.

The contrast estimates between the groups of assessed genotypes (Table 2) show that genotype PI 134417 was less preferred for oviposition and nymph survival than genotypes with low allelochemical contents (contrast $\mathrm{C} 1$ ), indicating the probable effect of the allelochemicals and of high glandular trichome density on the resistance to the pest.

Contrasts $\mathrm{C} 2, \mathrm{C} 3$, and $\mathrm{C} 4$ indicated that the allelochemicals 2-TD, AS, and ZGB at the levels exhibited by lines TOM-622, TOM-687, and ZGB-703, respectively, were broadly effective in the induction of a lower preference for oviposition and lower number nymphs compared to the lines with low contents of these allelochemicals.

Lines TOM-687 and ZGB-703 exhibited equivalent levels of oviposition and nymph survival (contrast C7), whereas TOM-622 exhibited lower levels of oviposition and number of nymphs compared to TOM-687 (contrast C6) and slightly lower oviposition than ZGB-703 (contrast C8). Because TOM-687 is rated a standard resistant line, all three investigated lines exhibited satisfactory levels of resistance to the silverleaf whitefly, and the allelochemicals AS, ZGB, and 2-TD efficiently mediated resistance to the silverleaf whitefly in tomato plants. 
Table 1 - Number of eggs and nymphs of B. tabaci biotype B on different tomato genotypes.

\begin{tabular}{|c|c|c|}
\hline Treatment & $\begin{array}{l}\text { Average number of eggs } \\
\qquad / 2 \mathrm{~cm}^{2} \text { leaflet* }\end{array}$ & $\begin{array}{l}\text { Average number of nymphs } \\
\qquad / 2 \mathrm{~cm}^{2} \text { leaflet } *\end{array}$ \\
\hline 1) PI134417 & $3.25 \mathrm{~A}$ & $1.17 \mathrm{~A}$ \\
\hline 2) $\mathrm{BPX}$ - 367D-074-02 & $80.58 \mathrm{~B}$ & $50.67 \mathrm{BCD}$ \\
\hline 3) $\mathrm{BPX}-365 \mathrm{~F}-899-14-02-04$ & $81.92 \mathrm{~B}$ & $64.92 \mathrm{EFG}$ \\
\hline 4) $\mathrm{BPX}-365 \mathrm{~F}-899-14-02-03$ & $84.17 \mathrm{~B}$ & $62.75 \mathrm{DEFG}$ \\
\hline 5) $\mathrm{TOM}-622$ & $85.17 \mathrm{~B}$ & $49.58 \mathrm{BC}$ \\
\hline 6) $\mathrm{BPX}-365 F-751-10-01-01$ & $93.83 \mathrm{~B}$ & $69.25 \mathrm{FG}$ \\
\hline 7) $\mathrm{ZGB}-703$ & $95.08 \mathrm{~B}$ & $53.75 \mathrm{BCDE}$ \\
\hline 8) $\mathrm{BPX}$ - 367D-238-02 & $96.00 \mathrm{BC}$ & $44.42 \mathrm{~B}$ \\
\hline 9) $\mathrm{TOM}-687$ & $97.00 \mathrm{BC}$ & 58.17 CDEF \\
\hline 10) $\mathrm{BPX}-365 \mathrm{~F}-751-05-02-02$ & $113.17 \mathrm{CD}$ & $75.08 \mathrm{G}$ \\
\hline 11) $\mathrm{BPX}-365 \mathrm{~F}-751-05-01-03$ & $116.25 \mathrm{C}$ & $102.75 \mathrm{H}$ \\
\hline 12) $\mathrm{BPX}-365 \mathrm{~F}-751-10-01-02$ & $118.58 \mathrm{D}$ & $73.92 \mathrm{G}$ \\
\hline 13) BPX - 365F-899-07-04-02 & $123.83 \mathrm{DE}$ & 49.67 BC \\
\hline 14) $\mathrm{TOM}-679$ & 125.33 DE & $102.33 \mathrm{H}$ \\
\hline 15) TOM - 584 & $140.33 \mathrm{E}$ & $107.83 \mathrm{H}^{\prime 1}$ \\
\hline $\mathrm{F}$ & $83.12 *$ & $105.77 *$ \\
\hline $\mathrm{CV} \%$ & 8.79 & 9.98 \\
\hline$\Sigma$ & 3.48 & 2.62 \\
\hline
\end{tabular}

*Significant $(\mathrm{p} \leq 0.01)$ based on the $\mathrm{F}$ test. ${ }^{1}$ Means followed by the same letter in columns do not differ based on Tukey's test ( $\left.\mathrm{p} \leq 0.05\right)$.

Table 2 - Contrasts of interest estimates between groups of genotypes with different levels of allelochemicals.

\begin{tabular}{lcc}
\hline \multirow{2}{*}{ Identification of Contrasts } & \multicolumn{2}{c}{ Contrast Estimates } \\
\hline C1- (TOM-584 + TOM-679)/2 vs. PI 134417 & Number of Eggs & $103.92^{* *}$ \\
C2- (TOM-584 + TOM-679)/2 vs. TOM-622 & $129.58^{* *}$ & $55.50^{* *}$ \\
C3- (TOM-584 + TOM-679)/2 vs. TOM-687 & $47.67^{* *}$ & $46.92^{* *}$ \\
C4- (TOM-584 + TOM-679)/2 vs. ZGB-703 & $35.83^{* *}$ & $51.33^{* *}$ \\
C5- PI 134417 vs. TOM-622 & $37.75^{* *}$ & $-48.42^{* *}$ \\
C6- TOM-687 vs. TOM-622 & $-81.92^{* *}$ & $8.58^{*}$ \\
C7- TOM-687 vs. ZGB-703 & $11.83^{*}$ & $4.41^{\mathrm{ns}}$ \\
C8- TOM-622 vs. ZGB-703 & $1.92^{\mathrm{ns}}$ & $-4.17^{\mathrm{ns}}$ \\
C9- TOM-687 vs. BPX - 365F-751-05-01-03 & $-9.92^{*}$ & $-44.58^{* *}$ \\
C10- TOM-687 vs. BPX - 365F-751-05-02-02 & $-19.25^{* *}$ & $-16.92^{* *}$ \\
C11- TOM-687 vs. BPX - 365F-751-10-01-01 & $-16.17^{* *}$ & $-11.08^{* *}$ \\
C12- TOM-687 vs. BPX - 365F-751-10-01-02 & $3.17^{\mathrm{ns}}$ & $-15.75^{* *}$ \\
C13- TOM-687 vs. BPX - 365F-899-07-04-02 & $-21.58^{* *}$ & $8.50^{*}$ \\
C14- TOM-687 vs. BPX - 365F-899-14-02-03 & $-26.83^{* *}$ & $-4.58^{\mathrm{ns}}$ \\
C15- TOM-687 vs. BPX - 365F-899-14-02-04 & $12.83^{*}$ & $-6.75^{\mathrm{ns}}$ \\
C16- TOM-687 vs. BPX - 367D-074-02 & $15.08^{* *}$ & $7.50^{*}$ \\
C17- TOM-687 vs. BPX - 367D-238-02 & $16.42^{* *}$ & $13.75^{* *}$ \\
\hline
\end{tabular}

${ }^{\mathrm{ns}}$ Not significant $(\mathrm{p}>0.05)$ based on the $\mathrm{F}$ test;

**, * Significant $(\mathrm{p} \leq 0.01)$ and $(\mathrm{p} \leq 0.05)$, respectively, based on the $\mathrm{F}$ test. 
Among the lines selected for high glandular trichome density, three (BPX-365F-751-05-01-03, BPX365F-751-05-02-02, and BPX-365F-751-10-01) exhibited lower levels of resistance than the standard resistant line, TOM-687, as measured based on oviposition and the number of nymphs (contrasts C9, C10, and C12, Table 2). However, four lines (BPX-365F-899-07-04-02, BPX-365F899-14-02-03, BPX-365F-899-14-02-04, and BPX-367D-07402) exhibited lower or similar numbers of nymphs compared to TOM-687 (contrasts C13, C14, C15, and C16); line BPX-365F-751-10-01-01 exhibited equivalent oviposition and more nymphs compared to the standard line, TOM-687 (contrast C11), and BPX-367D-238-02 exhibited similar oviposition and fewer nymphs compared to TOM-687 (contrast C17) (Table 2). Therefore, lines BPX365F-899-07-04-02, BPX-365F-899-14-02-03, BPX-365F899-14-02-04, BPX-367D-074-02, and, most importantly, BPX-365F-751-10-01-01 and BPX-367D-238-02 can be considered to exhibit satisfactory levels of resistance to the silverleaf whitefly. All lines selected based on high trichome density except for one (BPX-365F-751-05-01-03) (Table 1) exhibited fewer nymphs, on average, than the susceptible controls (TOM-584 and TOM-679), indicating that selection for more glandular trichomes (Table 3) was generally effective in promoting increased resistance to the silverleaf whitefly with almost perfect negative correlations (Table 4), particularly with regard to the adaxial trichomes. This seems to be indicative favorable because Rodriguez-Lopez et al. (2012) observed in genotype tomato ABL 14-8 preference of whitefly in ovopositar on adaxial side, with change in the behavior of the insect, by not eating so efficient and making it vulnerable to natural enemies.

Similar results as indirect selection were found by Oliveira et al. (2012), selected genotypes with the highest trichome density and found levels of resistance to the moth Tuta absoluta that were much higher than those exhibited by susceptible controls, and treatment BPX-367D-238-02 was particularly effective. Maluf et al. (2007) found similar results of indirect selection for resistance to the red spider mite $T$. urticae. This finding indicates that a correlation exists between trichome density and silverleaf whitefly oviposition; that is, the higher the glandular trichome density, the lower the level of oviposition (Tables 3 and 4). Oriani, Vendramim and Vasconcelos (2011) found genotypes with very high antixenosis with regard to oviposition associated with the presence of type IV glandular trichomes. According to Aragão, Dantas and Benitas (2000), who identified and quantified foliar trichomes in tomato specimens, leaflets with the highest concentrations of 2-TD were associated with the highest glandular trichome densities. However, that correlation was not perfect because the measurement of glandular trichome density is associated with sampling error and does not consider possible differences in the concentration of allelochemicals in each trichome.

Table 3 - Mean density $\left(\mathrm{n}^{\%} / \mathrm{cm}^{2}\right)$ of glandular trichomes on the abaxial side and adaxial side and the total glandular density on both sides of the plants obtained during the tomato genotype selection for the highest density of trichomes performed by Maluf et al. (2007).

\begin{tabular}{|c|c|c|c|c|c|c|c|}
\hline \multirow[b]{2}{*}{ Treatment } & \multicolumn{3}{|c|}{ Abaxial } & \multicolumn{3}{|c|}{ Adaxial } & \multirow{2}{*}{$\begin{array}{c}\text { Mean } \\
\text { Total } \\
\text { gland }\end{array}$} \\
\hline & IV & VI & $\begin{array}{l}\text { Total } \\
\text { gland }\end{array}$ & IV & VI & $\begin{array}{l}\text { Total } \\
\text { gland }\end{array}$ & \\
\hline 1) $\mathrm{TOM}-584$ & 0.00 & 0.00 & 0.00 & 0.00 & 246.70 & 246.70 & 123.30 \\
\hline 2) $\mathrm{TOM}-679$ & 0.00 & 986.70 & 986.70 & 0.00 & 246.70 & 246.70 & 1233.30 \\
\hline 3) $\mathrm{BPX}-365 \mathrm{~F}-751-05-01-03$ & 0.00 & 1480.00 & 1480.00 & 0.00 & 986.70 & 986.70 & 1233.30 \\
\hline 4) $\mathrm{BPX}-365 \mathrm{~F}-751-05-02-02$ & 0.00 & 2466.70 & 2466.70 & 0.00 & 1480.00 & 1480.00 & 1973.30 \\
\hline 5) $\mathrm{BPX}-365 \mathrm{~F}-751-10-01-01$ & 0.00 & 1973.30 & 1973.30 & 0.00 & 986.70 & 986.70 & 1480.00 \\
\hline 6) $\mathrm{BPX}-365 \mathrm{~F}-751-10-01-02$ & 0.00 & 986.70 & 986.70 & 0.00 & 1480.00 & 1480.00 & 1233.30 \\
\hline 7) $\mathrm{BPX}-365 \mathrm{~F}-899-07-04-02$ & 0.00 & 3946.70 & 3946.70 & 0.00 & 493.30 & 986.70 & 2466.70 \\
\hline 8) BPX - 365F-899-14-02-03 & 0.00 & 1480.00 & 1480.00 & 0.00 & 1480.00 & 1480.00 & 1480.00 \\
\hline 9) $\mathrm{BPX}-365 \mathrm{~F}-899-14-02-04$ & 0.00 & 1480.00 & 1480.00 & 0.00 & 1973.30 & 2466.70 & 1973.30 \\
\hline 10) BPX - 367D-074-02 & 0.00 & 1480.00 & 1480.00 & 0.00 & 986.70 & 1480.00 & 1480.00 \\
\hline 11) BPX - 367D-238-02 & 0.00 & 493.30 & 986.70 & 0.00 & 986.70 & 986.70 & 986.70 \\
\hline
\end{tabular}

IV = type IV trichome; VI = type VI trichome ;Gland = glandular density. 
Table 4 - Correlations between glandular trichome density and the number of eggs $\left(\mathrm{n}^{\circ} \mathrm{eggs} / 2 \mathrm{~cm}^{2}\right)$ of $B$. tabaci biotype B calculated (1) using "TOM-584" and lines BPX-367D-074-02 and BPX-367D-238-02 and (2) using "TOM-679" and lines BPX-365F-751-05-01-03, BPX-365F-751-05-02-02, BPX-365F-751-10-01-01, BPX-365F-751-10-01-02, BPX-365F-89907-04-02, BPX-365F-899-14-02-03, and BPX-365F-899-14-02-04. Lavras-MG, UFLA, 2009.

\begin{tabular}{|c|c|c|}
\hline & \multicolumn{2}{|c|}{ Selected genotypes } \\
\hline & $\begin{array}{c}\text { TOM-584. (BPX- } \\
\text { 367D-074-02 and BPX- } \\
\text { 367D-238-02) }\end{array}$ & $\begin{array}{c}\text { TOM-679. (BPX-365F-751-05-01-03, } \\
\text { BPX-365F-751-05-02-02, BPX-365F- } \\
\text { 751-10-01-01, BPX-365F-751-10-01- } \\
\text { 02, BPX-365F-899-07-04-02, BPX- } \\
\text { 365F-899-14-02-03, and BPX-365F- } \\
\text { 899-14-02-04) }\end{array}$ \\
\hline Correlation with type IV trichomes (Ab) & $0.00^{\mathrm{ns}}$ & $0.00^{\mathrm{ns}}$ \\
\hline Correlation with type VI trichomes (Ab) & $-0.89^{*}$ & $0.21^{\mathrm{ns}}$ \\
\hline Correlation with total glandular trichomes $(\mathrm{Ab})$ & $-0.99^{*}$ & $0.21^{\mathrm{ns}}$ \\
\hline Correlation with type IV trichomes (Ad) & $0.00^{\mathrm{ns}}$ & $0.00^{\mathrm{ns}}$ \\
\hline Correlation with type VI trichomes (Ad) & $-0.97^{*}$ & $-0.69 *$ \\
\hline Correlation with total glandular trichomes (Ad) & $-0.99^{*}$ & $-0.68^{*}$ \\
\hline Correlation total glandular (mean) & $-0.99^{*}$ & $-0.04^{\mathrm{ns}}$ \\
\hline
\end{tabular}

$\mathrm{Ab}=$ abaxial surface $\mathrm{Ad}=$ adaxial surface.

${ }^{*}$ significant $(\mathrm{p}<0.05)$; ${ }^{\mathrm{ns}}$ not significant.

Analogous results with the allelochemicals AS and ZGB were found by Silva et al. (2009), in which AS-rich (TOM-688 and TOM-689) and ZGB-rich (ZGB-703 and ZGB-704) lines exhibited greater resistance to the silverleaf whitefly. However, Silva et al. (2009) observed that ZGB was significantly more efficient than $\mathrm{AS}$ in reducing number nymphs, indicating that ZGB may bestow a higher degree of antixenosis than AS.

Large differences in oviposition and reduced nymph survival were not observed in the present study between the AS-rich (TOM-687), 2-TD-rich (TOM-622), and ZGB-rich (ZGB-703) lines (Table 1), except for contrast C6 (Table 2); this finding appears to indicate that 2-TD induced less preference for oviposition and number nymphs than AS.

\section{CONCLUSIONS}

Various allelochemicals (2-TD, ZGB, and AS) bestow similar degrees of resistance to the silverleaf whitefly, however genotypes with high levels of these allelochemicals may differ slightly among themselves as to the level of resistance, depending on the background genotype considered. In addition, glandular trichome density can be efficiently used as an indirect selection criterion for resistance to the silverleaf whitefly.

\section{ACKNOWLEDGMENTS}

The authors thank the Minas Gerais Research Foundation (Fundação de Amparo à Pesquisa do Estado de Minas Gerais - FAPEMIG), the National Council of Scientific and Technological Development (Conselho Nacional de Desenvolvimento Científico e Tecnológico $\mathrm{CNPq}$ ), the Federal Agency for the Support and Evaluation of Graduate Education (Coordenação de Aperfeiçoamento de Pessoal de Nível Superior - CAPES) for financial support and study grants and HortiAgro Sementes SA for support.

\section{REFERENCES}

ARAGÃO, C.A.; DANTAS, B.F.; BENITES, F.R.G. Foliar trichomes in tomato plants with various allelochemical 2-tridecanone contents. Scientia Agricola, São Paulo, v.57, n.4, oct./dec, p.813-816, 2000.

BACCI, L. et al. Toxicity of insecticides to sweetpotato whitefly (Hemiptera: Aleyrodidae) and its natural enemies. Pest Management Science, Malden, v.63, p.699-706, 2007.

\section{CARTER, C.D.; SACALIS, J.N.; GIANFAGNA, T.J.}

Resistance to Colorado potato beetle in relation to the zingiberene content of Lycopersicon species. Report of Tomato Genetics Cooperative, Bradenton, v.38, jun, p.11$12,1988$. 
FERNANDES, M.E.S. et al. New accessions of tomato plant resistant to silverleaf whitefly biotype B. Pesquisa Agropecuária Brasileira, Brasília, v. 44, n.11, p.154515148, 2009.

FREITAS, J.A. et al. Inheritance of foliar zingiberene contents and their relationship to trichome densities and whitefly resistance in tomatoes. Euphytica, Alexandria, v.127, p.275-287, 2002.

GENNADIUS, P. Disease of the tobacco plantations in the Trikonia. The aleurodid of tobacco. Ellenike Georgia, Hobart, v. 5, p.1-3, 1889.

GONÇALVES NETO, A.C. et al. Resistência à traça-dotomateiro em plantas com altos teores de acilaçúcares nas folhas. Horticultura Brasileira, Brasília, v.28, n.2, abr./jun, p.203-208, 2010.

MALUF, W.R et al. Higher glandular trichome density in tomato leaflets and repellence to spider mites. Pesquisa Agropecuária Brasileira, Brasília, v.42, n.9, sept, p.12271235, 2007.

MALUF, W.R. et al. Broad-spectrum arthropod resistance in hybrids between high- and low-acylsugar tomato lines. Crop Science, Madison, v.50, p.439-450, 2010.

NOMBELA, G.; MUNIZ, M. Host plant resistance for the management of Bemisia tabaci: a multi-crop survey with an emphasis on the tomato. In: STANSLY, P.A., NARANJO, S.E. (Ed) Bemisia: Bionomics and Management of a Global Pest. New York, Springer, p.357-383, 2010.

OLIVEIRA, C.M. et al. Resistance of tomato biotypes to the moth Tuta absoluta imparted by allelochemicals and trichome density. Ciência e Agrotecnologia, Lavras, v.36, n.1, jan./fev., p.45-52, 2012.
ORIANI, M.A.G; VENDRAMIM, J.D.; VASCONCELOS, C.J. No-choice ovipositional nonpreference of Bemisia tabaci (Gennadius) B biotype on tomato genotypes. Scientia Agricol, SãoPaulo, v.68, n.2, mar./apr, p.147-153, 2011.

RODRÍGUEZ-LÓPEZ, M.J. et al. Acylsucrose-producing tomato plants forces Bemisia tabaci to shift its preferred settling and feeding site. Plos One, Madrid, v.07, n.3, mar, p.01-09, 2012.

\section{STATISTICALANALYSIS SYSTEM INSTITUE-SAS.} SAS/STAT user's guide. SAS Institute, Cary, NC. 1990.

SILVA, V.F. et al. Resistência mediada por aleloquímicos de genótipos de tomateiro à mosca-branca e ao ácarorajado. Pesquisa Agropecuária Brasileira, Brasília, v.44, n.9, sept, p.1262-1269, 2009.

TOSCANO, L.C.; BOIÇA JÚNIOR, A.L.; MARUYAMA, W.I. Nonpreference of whitefly for oviposition in tomato genotypes. Scientia Agricola, São Paulo, v.59, n.4, oct./ nov, p.677-681, 2002.

TORRES, L.C. et al. Biology and non-preference for oviposition of Bemisia tabaci (Gennadius) biotype B (Hemiptera: Aleyrodidae) in cultivars of cotton. Neotropical Entomology,Londrina, v.36, n.3, may.june, p.45-453, 2007.

VENDRAMIM, J.D. Traça Tuta absoluta (Meyrick) em cultivares de tomateiro tratadas com extratos aquosos de Trichilia pallida Swartz [Moth Tuta absoluta (Meyrick) in tomato cultivars treated with aqueous extracts of Trichilia pallida Swartz]. Scientia Agricola, São Paulo, v.58, n.3, jul./set, p.607-611, 2001.

VENDRAMIM, J.D.; SOUZA, A.P.; ONGARELLI, M.D. Oviposition behavior of silverleaf whitefly Bemisia tabaci (Genn.) (Hemiptera: Aleyrodidae) biotype B in tomato plant. Neotropical Entomology, Londrina, v.38, n.1,jan./feb, p.126-132, 2009. 